Available online at GSC Online Press Directory

GSC Biological and Pharmaceutical Sciences

e-ISSN: 2581-3250, CODEN (USA): GBPSC2

Journal homepage: https://www.gsconlinepress.com/journals/gscbps

(RESEARCH ARTICLE)

\title{
Effects of poultry manure based compost and NPK fertilizer on the growth and yield of sorghum (Sorghum bicolor L. moench) in Bauchi state Nigeria
}

\author{
Shuaibu Yunusa Muhammad*, Fagam Ahmed Sarki and Kawure Sani \\ Department of Crop Production, Faculty of Agriculture and Agricultural Technology, Abubakar Tafawa Balewa University \\ Bauchi, Nigeria.
}

Publication history: Received on 14 October 2017; revised on 16 November 2017; accepted on 08 January 2018

https://doi.org/10.30574/gscbps.2018.2.1.0047

\begin{abstract}
The experiment was conducted at the teaching and research farm of the Abubakar Tafawa Balewa University, Bauchi $\left(10^{\circ} 22^{\prime} \mathrm{N}\right.$ and $\left.9^{\circ} 47^{\prime} \mathrm{E}\right)$, to study the effects of poultry manure based compost, NPK fertilizer and spacing on the growth and yield of sorghum. The treatments consisted of Poultry manure based compost $(0,1$ and $2 \mathrm{t} / \mathrm{ha})$, NPK fertilizer $(0$, 30 and $60 \mathrm{~kg} / \mathrm{ha}$ ) and two spacings $(25 \mathrm{~cm} \times 75 \mathrm{~cm}$ and $30 \mathrm{~cm} \times 75 \mathrm{~cm})$. Factorially combined given 18 treatments combination, laid out in a randomized complete block design and replicated three times. Data collected was analysed using ANOVA and Duncan's Multiple Range Test was adopted to separate significantly different treatments means. The result of the experiment revealed that, application of $60 \mathrm{~kg} \mathrm{NPK}$ and $2 \mathrm{t} /$ ha poultry manure based compost proved to be significantly $(\mathrm{P}=0.05)$ better in promoting growth and yield of sorghum than all other rates and all the rates were better than the control. Considering spacing however, growing sorghum spaced at $30 \mathrm{~cm} \mathrm{x} 75 \mathrm{~cm}$ gave significantly $(\mathrm{P}=0.05)$ higher growth and yield than $25 \mathrm{~cm} \times 75 \mathrm{~cm}$. Study on interaction revealed that, combine application of $60 \mathrm{~kg}$ NPK/ha and $2 \mathrm{t} /$ ha poultry manure based compost gave significantly $(\mathrm{P}=0.05)$ higher growth and yield of sorghum. Based on this result, combine application of NPK fertilizer and poultry manure based compost to sorghum spaced at 30 $\mathrm{x} 75 \mathrm{~cm}$ will address the issue of soil fertility in the study area.
\end{abstract}

Keywords: Poultry manure; Compost; Sorghum; Fertilizer; Yield

\section{Introduction}

In sub-Saharan Africa, crop yields are limited by many factors, one of which is nutrient deficiencies. Soils have inherently low levels of nutrients because of low soil organic matter levels and limited use of nutrient inputs by farmers. Nitrogen $(\mathrm{N})$ and phosphorous (P) deficiencies are the main soil fertility constraints in most of the soils of West Africa [1]. Chemical fertilizers are imported from developed countries and remain expensive for poor farmers who therefore, never use them or only occasionally apply small quantities. While $73 \mathrm{~kg} / \mathrm{ha}$ of chemical fertilizer is used by farmers in Asia, only $8 \mathrm{~kg} / \mathrm{ha}$ is used in Africa [2]. The ever increasing population of many countries of the world has necessitated the development of intensive agricultural technologies to sustain food production and yield. In recent years, the increase in population had led to pressure on farm land through intensive cultivation of soil, leading to nutrients depletion. Declining soil fertility is a major production constraint in Africa, especially Nigeria and it is becoming increasingly critical to secure sustainable soil productivity. Soil fertility maintenance is essential in achieving and maintaining high crop yields over a period of time. Therefore, maintaining and improving soil fertility through the application of fertilizers is an essential factor enabling the world to feed the increasing population [3]. Inorganic fertilizers have been used as a way of sustaining soil productivity which have proved to be more convenient than the use of organic fertilizers that have traditionally been used since pre- industrial age.

\footnotetext{
${ }^{*}$ Corresponding author

E-mail address: ymshuaibu@ atbu.edu.ng
}

Copyright (C) 2018 Author(s) retain the copyright of this article. This article is published under the terms of the Creative Commons Attribution Liscense 4.0. 
Crop growth, yield and product quality in relation to application of different organic fertilizers has been widely reported [4-5]. Addition of organic materials of various origins to soil has been one of the most common practices to improve soil physical properties and the use of compost on crops have been reported to improve crop yield and quality and play a key role in the maintenance of soil productivity [6]. Emerging evidence indicates that integrated soil fertility management involving the judicious use of combinations of organic and inorganic resources is a feasible approach to overcome soil fertility constraints [7-9]. Despite lack of staple food supply and the importance of cereal crops notably sorghum as a source of carbohydrate, savannah soils are low in fertility and cannot satisfactorily support crops like sorghum and maize without the addition of fertilizer. Mineral fertilizers on the other hand are generally costly and unavailable to the small scale farmers. Mineral fertilizers even when available could be environmentally unsafe and most of the farmers do not know how to use them for optimum production. There has been an increasing environmental concern about damage caused by agricultural activities worldwide, as a result of using agrochemicals [10]. This call for a search of alternative cropping system and organic agriculture has been established as a safer system in many countries and this has necessitated the use of inorganic fertilizers especially in compost forms. There is paucity of documented information on similar practices for sorghum production especially in the northern guinea savanna zone of Nigeria. This study was carried out to determine the effects of poultry manure based compost, its combination with NPK fertilizer and spacing on the growth and yield of sorghum.

\section{Material and methods}

The experiment was conducted at the teaching and research farm of the Faculty of agriculture and agricultural technology, Abubakar Tafawa Balewa University, Bauchi $\left(10^{\circ} 22^{\prime} \mathrm{N}\right.$ and $\left.9^{\circ} 47^{\prime} \mathrm{E}\right)$. Bauchi is located in the Northern Guinea savannah agro ecological zone of Nigeria. The materials used for the experiment consisted of poultry manure based compost, NPK fertilizer (20:10:10) and sorghum (variety; CRS-01). Poultry manure based compost was obtained from Bauchi state Agricultural Development Programme (BSADP) while NPK fertilizer and Sorghum (variety; CRS-01) were obtained from Bauchi state Agricultural Supply Company (BASAC). The treatments consisted of Poultry manure based compost $(0,1$ and $2 \mathrm{t} / \mathrm{ha})$, NPK fertilizer $(0,30$ and $60 \mathrm{~kg} / \mathrm{ha})$ and two spacings $(25 \mathrm{~cm} \mathrm{x} 75 \mathrm{~cm}$ and $30 \mathrm{~cm} \times 75$ $\mathrm{cm}$ ). These were factorially combined to give a total of 18 treatments combination and laid out in a randomized complete block design (RCBD) with three replications. Net plot size of $4 \mathrm{~m}^{2}$ was adopted for the experiment and a border row of $50 \mathrm{~cm}$ was left between plots while $200 \mathrm{~cm}$ was left out as a walk way between replications. The experimental site was ploughed and harrowed followed by laying out of the experimental plots. The sorghum seed was sown at a spacing of $25 \mathrm{~cm} \times 75 \mathrm{~cm}$ and $30 \mathrm{~cm} \times 75 \mathrm{~cm}$ intra and inter row spacing respectively. Six seeds were planted and later thinned to two plants per stand at two weeks of emergence. The compost (poultry manure based compost) was applied during land preparation and NPK fertilizer was applied in two split doses, first at one week and the second at five weeks after emergence. The experimental site was treated by the application of Paraquat after land preparation to get rid of the emerged weeds. However, manual weeding was carried out at 2 and 5 weeks after emergence using hand hoe. The sorghum plants were first harvested by cutting down the entire plant at maturity while the panicles were removed using knife manually and was left to dry under the sun for a week. The dried panicles were then threshed manually with stick and winnowed to remove chaff. Data were collected by selecting five plants randomly from the net plot on the following parameters: plant height, number of leaves per plant, leaf area and panicle length. Others are number of spikes per panicle, 1000 grain weight and grain yield.

\subsection{Data analysis}

All data collected were subjected to analysis of variance (ANOVA) and Duncan's Multiple Range Test (DMRT) was adopted during the analysis to separate significantly different treatments means.

\section{Results and discussion}

\subsection{Effects of Poultry Manure Based Compost, Spacing and NPK Fertilizer on Growth Characters of Sorghum}

\subsubsection{Plant height}

The significant $(\mathrm{P} \leq 0.05)$ difference observed throughout the study period on plant height of sorghum in which the application of $60 \mathrm{~kg} \mathrm{NPK} /$ ha proved to be better than all the rates used, indicated that increasing inorganic fertilizer level increases growth of sorghum. The present study supported the earlier report of [11-12], who reported that increasing nitrogen fertilizer increases plant growth. The increase in plant height due to increase in poultry manure based compost could be as a result of low carbon to nitrogen ratio of poultry manure and the effect of decomposition which lead to early release of plant nutrient in the soil. This is in line with the report of [13] who reported that composting organic matter will increase not only growth of crop, but also its nitrogen use efficiency. With regards to 
spacing however, taller plants were observed with wider spacing. The result of this study is not in line with the result of [14] who reported that tallest plants were observed with closer spacing due to the effect of competition.

Table 1 Effects of poultry manure based compost, spacing and NPK fertilizer on plant height of sorghum

\begin{tabular}{|c|c|c|c|c|}
\hline \multirow{2}{*}{ Treatments } & \multicolumn{4}{|c|}{ WAS } \\
\hline & 4 & 6 & 8 & 10 \\
\hline \multicolumn{5}{|l|}{ NPK (kg/ha) } \\
\hline 0 & $37.99^{c}$ & $88.39^{c}$ & $154.01^{\mathrm{b}}$ & $183.46^{b}$ \\
\hline 30 & $46.57^{b}$ & $104.05^{b}$ & $183.56^{\mathrm{a}}$ & $201.46^{\mathrm{a}}$ \\
\hline 60 & $51.32^{\mathrm{a}}$ & $109.32^{\mathrm{a}}$ & $195.28^{a}$ & $163.33^{c}$ \\
\hline LS & $* *$ & $* *$ & $* *$ & $* *$ \\
\hline $\mathrm{SE} \pm$ & 0.85 & 1.50 & 5.15 & 5.24 \\
\hline \multicolumn{5}{|l|}{ Compost (t/ha) } \\
\hline 0 & $39.71^{c}$ & $85.54^{c}$ & $159.42^{\mathrm{b}}$ & $165.43^{c}$ \\
\hline 1 & $44.76^{b}$ & $103.93^{b}$ & $172.82^{b}$ & $182.18^{\mathrm{b}}$ \\
\hline 2 & $51.44^{\mathrm{a}}$ & $112.28^{\mathrm{a}}$ & $200.60^{\mathrm{a}}$ & $199.64^{\mathrm{a}}$ \\
\hline LS & $* *$ & $* *$ & $* *$ & $* *$ \\
\hline $\mathrm{SE} \pm$ & 0.85 & 1.50 & 5.15 & 5.24 \\
\hline \multicolumn{5}{|l|}{ Spacing } \\
\hline $25 \mathrm{~cm} \times 75 \mathrm{~cm}$ & 45.66 & 100.56 & 174.49 & $176.27^{b}$ \\
\hline $30 \mathrm{~cm} \mathrm{x} 75 \mathrm{~cm}$ & 44.95 & 100.60 & 180.74 & $188.56^{\mathrm{a}}$ \\
\hline LS & NS & NS & NS & $*$ \\
\hline $\mathrm{SE} \pm$ & 0.69 & 1.22 & 4.20 & 4.03 \\
\hline \multicolumn{5}{|l|}{ Interaction } \\
\hline NXC & NS & $*$ & NS & $* *$ \\
\hline NXS & $* *$ & NS & NS & NS \\
\hline CXS & NS & NS & NS & NS \\
\hline
\end{tabular}

Table 2 Interaction of NPK fertilizer and poultry manure based compost on plant height

\begin{tabular}{ccccccc}
\hline Compost & \multicolumn{3}{c}{$\mathbf{6}$ WAS } & \multicolumn{3}{c}{$\mathbf{1 0}$ WAS } \\
\cline { 2 - 7 } NPK (kg) & $\mathbf{0}$ & $\mathbf{1}$ & $\mathbf{2}$ & $\mathbf{0}$ & $\mathbf{1}$ & $\mathbf{2}$ \\
\hline 0 & $67.30^{\mathrm{f}}$ & $95.10^{\mathrm{de}}$ & $102.77^{\mathrm{cd}}$ & $160.15^{\mathrm{cd}}$ & $182.34^{\mathrm{bc}}$ & $153.81^{\mathrm{d}}$ \\
30 & $91.77^{\mathrm{e}}$ & $107.49^{\mathrm{bc}}$ & $112.88^{\mathrm{b}}$ & $183.18^{\mathrm{bc}}$ & $180.93^{\mathrm{bc}}$ & $182.44^{\mathrm{bc}}$ \\
60 & $97.56^{\mathrm{de}}$ & $109.20^{\mathrm{bc}}$ & $121.19^{\mathrm{a}}$ & $207.04^{\mathrm{b}}$ & $241.12^{\mathrm{a}}$ & $250.76^{\mathrm{a}}$ \\
LS & & $*$ & & & $*^{2}$ \\
SE \pm & & 2.59 & & & 9.08 & \\
\hline
\end{tabular}

LS = Level of significance, SE = Standard error, NS = Not significant ${ }^{*} \&{ }^{* *}=$ Significant $@ 0.05 \& 0.01$ probability level, Means followed by the same letter in a column are statistically same by DMRT.

\subsubsection{Number of leaves}

The significant $(\mathrm{P} \leq 0.05)$ difference observed on number of leaves throughout the study period on various level of NPK fertilizer, in which the rate of $60 \mathrm{~kg} /$ ha proved to be superior to other treatment used, revealed the effect of NPK fertilizer as well as its importance in cropping system. This confirm the result of [15-16] who reported that inorganic fertilizer application levels has a significant contribution on vegetative growth of plants. The study further indicated that increasing level of compost increased number of leaves of sorghum. This could be due to the effects of compost on vegetative growth of plant. The present study corroborate with that of [17] who reported that number of leaves of sorghum is a result of increase in plant height. The findings of this study shows no significant difference in terms of 
plant density on number of leaves. This result lend its support from the findings of [18] who said that no significant difference was manifested in leaf number as a result of an increase in plant density.

Table 3 Effects of poultry manure based compost, spacing and NPK fertilizer on number of leaves of sorghum

\begin{tabular}{|c|c|c|c|c|}
\hline \multirow{2}{*}{ Treatments } & \multicolumn{4}{|c|}{ WAS } \\
\hline & 4 & 6 & 8 & 10 \\
\hline \multicolumn{5}{|l|}{ NPK (kg/ha) } \\
\hline 0 & $6.67^{b}$ & $9.48^{\mathrm{b}}$ & $11.36^{b}$ & $10.63^{c}$ \\
\hline 30 & $7.18^{\mathrm{a}}$ & $10.45^{\mathrm{a}}$ & $12.26^{\mathrm{a}}$ & $12.20^{\mathrm{b}}$ \\
\hline 60 & $7.28^{\mathrm{a}}$ & $8.97^{b}$ & $10.99 \mathrm{~b}$ & $12.75^{\mathrm{a}}$ \\
\hline LS & $* *$ & $* *$ & $* *$ & $* *$ \\
\hline $\mathrm{SE} \pm$ & 0.14 & 0.26 & 0.28 & 0.19 \\
\hline \multicolumn{5}{|l|}{ Compost (t/ha) } \\
\hline 0 & $6.60^{c}$ & 9.31 & $10.92^{b}$ & $11.05^{c}$ \\
\hline 1 & $6.96^{b}$ & 9.51 & $11.68^{\mathrm{ab}}$ & $11.80^{\mathrm{b}}$ \\
\hline 2 & $7.57^{\mathrm{a}}$ & 10.08 & $12.01^{\mathrm{a}}$ & $12.73^{\mathrm{a}}$ \\
\hline LS & $* *$ & NS & $* *$ & $* *$ \\
\hline $\mathrm{SE} \pm$ & 0.14 & 0.26 & 0.28 & 0.19 \\
\hline \multicolumn{5}{|l|}{ Spacing } \\
\hline $25 \mathrm{~cm} \times 75 \mathrm{~cm}$ & 6.97 & 9.46 & 11.34 & 11.70 \\
\hline $30 \mathrm{~cm} \mathrm{x} 75 \mathrm{~cm}$ & 7.12 & 9.80 & 11.73 & 12.02 \\
\hline LS & NS & NS & NS & NS \\
\hline $\mathrm{SE} \pm$ & 0.11 & 0.21 & 0.23 & 0.15 \\
\hline \multicolumn{5}{|l|}{ Interaction } \\
\hline NXC & NS & NS & NS & NS \\
\hline NXS & NS & NS & NS & NS \\
\hline CXS & NS & NS & NS & NS \\
\hline
\end{tabular}

\subsubsection{Leaf area}

The higher leaf area as observed through the application of $60 \mathrm{~kg} \mathrm{NPK} /$ ha could be as a result of increase in plant growth as influenced by the inorganic fertilizer. The increase in leave area as a result of increase in application of NPK fertilizer also indicated the importance of inorganic fertilizer in cereal production. This proved the result of [11] who reported that increasing inorganic fertilizer increased growth characters of plant. Sorghum grown with the application of 2 tons of poultry manure based compost tend to promote larger surface area for sunlight and $\mathrm{CO}_{2}$ absorption.

The present finding is in agreement with that of [19] who reported that the use of compost in cereal farming in the savannah zone of Nigeria has a significant effect on the growth of cereals. An earlier study by [20] also lend support to the present results obtained. No significant difference was observed with respect to plant density. This result lend its support from the findings of [18] who said that no significant difference was manifested in leaf number as a result of an increase in plant density. Combine application of NPK fertilizer and compost at a rate of $60 \mathrm{~kg}+2 \mathrm{t} / \mathrm{ha}$ gave better ground cover. This indicated the importance of combine application of organic and inorganic fertilizer in sorghum production. This corroborate with the finding of [21] who reported that, compost application maintain higher level of organic carbon and inorganic fertilizer use efficiency than sole application of inorganic fertilizer. 
Table 4 Effects of poultry manure based compost, spacing and NPK fertilizer on leaf area of sorghum

\begin{tabular}{|c|c|c|c|c|}
\hline \multirow[t]{2}{*}{ Treatments } & \multicolumn{4}{|c|}{ WAS } \\
\hline & 4 & 6 & 8 & 10 \\
\hline \multicolumn{5}{|l|}{ NPK (kg/ha) } \\
\hline 0 & $65.18^{\mathrm{b}}$ & $316.52^{c}$ & $551.35^{\mathrm{b}}$ & $553.55^{b}$ \\
\hline 30 & $93.75^{\mathrm{a}}$ & $428.55^{b}$ & $676.64^{\mathrm{a}}$ & $678.96^{\mathrm{a}}$ \\
\hline 60 & $106.49^{a}$ & $480.94^{\mathrm{a}}$ & $711.27^{\mathrm{a}}$ & $715.71^{\mathrm{a}}$ \\
\hline LS & $* *$ & $* *$ & $* *$ & $* *$ \\
\hline $\mathrm{SE} \pm$ & 5.16 & 16.61 & 17.47 & 16.94 \\
\hline \multicolumn{5}{|l|}{ Compost (t/ha) } \\
\hline 0 & $70.35^{b}$ & $346.21^{b}$ & $586.85^{b}$ & $591.11^{b}$ \\
\hline 1 & $84.38^{b}$ & $392.03^{\mathrm{b}}$ & $656.00^{\mathrm{a}}$ & $657.70^{\mathrm{a}}$ \\
\hline 2 & $110.89^{a}$ & $487.77^{a}$ & $696.40^{a}$ & $699.41^{\mathrm{a}}$ \\
\hline LS & $* *$ & $* *$ & $* *$ & $* *$ \\
\hline $\mathrm{SE} \pm$ & 5.16 & 16.61 & 17.47 & 16.94 \\
\hline \multicolumn{5}{|l|}{ Spacing } \\
\hline $25 \mathrm{~cm} \mathrm{x} 75 \mathrm{~cm}$ & 88.42 & 393.74 & 634.91 & 638.04 \\
\hline $30 \mathrm{~cm} \mathrm{x} 75 \mathrm{~cm}$ & 88.54 & 423.60 & 657.92 & 660.77 \\
\hline LS & NS & NS & NS & NS \\
\hline $\mathrm{SE} \pm$ & 4.21 & 13.56 & 14.26 & 13.83 \\
\hline \multicolumn{5}{|l|}{ Interaction } \\
\hline NXC & NS & NS & NS & $*$ \\
\hline NXS & NS & NS & NS & NS \\
\hline CXS & NS & NS & NS & NS \\
\hline
\end{tabular}

LS = Level of significance, SE = Standard error, NS = Not significant, ${ }^{*} \&{ }^{* *}=$ Significant $@ 0.05 \& 0.01$ probability level, Means followed by the same letter in a column are statistically same by DMRT.

Table 5 Interaction of NPK fertilizer and poultry manure based compost on leaf area at 10 WAS

\begin{tabular}{|c|c|c|c|}
\hline \multirow[t]{2}{*}{ NPK (kg) } & \multicolumn{3}{|c|}{ Compost (t/ha) } \\
\hline & $\mathbf{0}$ & 1 & 2 \\
\hline 0 & $462.88^{e}$ & $551.12^{\mathrm{d}}$ & $646.65^{b c}$ \\
\hline 30 & $609.41^{c d}$ & $731.25^{\mathrm{ab}}$ & $696.24^{\mathrm{abc}}$ \\
\hline 60 & $701.04^{\mathrm{ab}}$ & $690.74^{\mathrm{abc}}$ & $755.35^{a}$ \\
\hline LS & & $*$ & \\
\hline $\mathrm{SE} \pm$ & & 29.34 & \\
\hline
\end{tabular}

\subsection{Effects of Poultry Manure Based Compost, Spacing and NPK Fertilizer on yield and yield component of sorghum}

\subsubsection{Panicle length $(\mathrm{cm})$}

The result on panicle length showed that, the rate of $60 \mathrm{~kg}$ NPK/ha was found to be better than the other rates, this indicated the importance of inorganic fertilizer in crop production. The increase in panicle length could be as a result of increasing NPK fertilizer level. This revealed the importance of $\mathrm{N}$ as a basic component of plant physiological activities as supported by [11] working on nitrogen fertilizer in cereal production. The increased in head length of sorghum is due to increase in soil organic carbon due to the application of poultry manure based compost. The result of the present study lend its support from the result of [19], who reported a significant effect of compost on soil fertility in the Sudan savannah zone of Nigeria. The significant difference observed on plant density in which spacing of $30 \mathrm{x} 75 \mathrm{~cm}$ gave 
bigger head of sorghum indicated the effect of wider spacing in sorghum production. This could be as a result of reduced competition of water and nutrient between the plants. This is in line with the report of [22] who reported a significant effect of spacing on yield components of sorghum. The result of the interaction revealed that, sorghum can be grown successful with the combine application of $60 \mathrm{~kg}$ NPK and $2 \mathrm{t} / \mathrm{ha}$ of compost with wider spacing. This could be as a result of better utilization of fertilizer nutrient as a result of increase in organic carbon in the soil. The result of this findings lend its support to the finding of [21] who reported that, nitrogen availability after application of compost is increased and is under the influence of weather conditions especially rainfall and temperature.

Table 6 Effects of poultry manure based compost, spacing and NPK fertilizer on Panicle length, Number of spikes/panicle, 1000 grain weight and Grain yield

\begin{tabular}{|c|c|c|c|c|}
\hline Treatments & Panicle length & No. of spike & 1000 grain weight & Grain yield \\
\hline \multicolumn{5}{|l|}{ NPK (kg/ha) } \\
\hline 0 & $31.61^{c}$ & $48.79^{c}$ & $24.45^{c}$ & $2110.04^{c}$ \\
\hline 30 & $35.06^{b}$ & $53.74^{b}$ & $26.73^{b}$ & $2571.72^{b}$ \\
\hline 60 & $37.26^{\mathrm{a}}$ & $60.82^{\mathrm{a}}$ & $28.96^{\mathrm{a}}$ & $2952.32^{\mathrm{a}}$ \\
\hline LS & $* *$ & $* *$ & $* *$ & $* *$ \\
\hline $\mathrm{SE} \pm$ & 0.31 & 0.54 & 0.36 & 54.22 \\
\hline \multicolumn{5}{|c|}{ Compost (t/ha) } \\
\hline 0 & $30.35^{c}$ & $44.75^{c}$ & $23.52^{c}$ & $2073.65^{c}$ \\
\hline 1 & $33.78^{b}$ & $56.91^{b}$ & $27.24 b$ & $2470.43^{b}$ \\
\hline 2 & $39.80^{\mathrm{a}}$ & $61.68^{a}$ & $29.37^{a}$ & $3091.68^{a}$ \\
\hline LS & $* *$ & $* *$ & $* *$ & $* *$ \\
\hline $\mathrm{SE} \pm$ & 0.31 & 0.54 & 0.36 & 54.22 \\
\hline \multicolumn{5}{|l|}{ Spacing } \\
\hline $25 \mathrm{~cm} \mathrm{x} 75 \mathrm{~cm}$ & $33.82^{b}$ & $53.34^{b}$ & 26.64 & $2431.12^{b}$ \\
\hline $30 \mathrm{~cm} \times 75 \mathrm{~cm}$ & $35.46^{\mathrm{a}}$ & $55.56^{\mathrm{a}}$ & 26.78 & $2662.63^{\mathrm{a}}$ \\
\hline LS & $* *$ & $* *$ & NS & $* *$ \\
\hline $\mathrm{SE} \pm$ & 0.25 & 0.44 & 0.29 & 44.27 \\
\hline \multicolumn{5}{|l|}{ Interaction } \\
\hline $\mathrm{NXC}$ & $* *$ & $* *$ & NS & $* *$ \\
\hline NXS & NS & NS & NS & NS \\
\hline CXS & $* *$ & NS & NS & NS \\
\hline
\end{tabular}

LS = Level of significance, $\mathrm{SE}=$ Standard error, NS = Not significant, ${ }^{*} \&{ }^{* *}=$ Significant $@ 0.05 \& 0.01$ probability level, Means followed by the same letter in a column are statistically same by DMRT.

\subsubsection{Number of spikes per panicle}

Table 7 Interaction of NPK fertilizer and poultry manure based compost on Panicle length and Number of spike/panicle

\begin{tabular}{|c|c|c|c|c|c|c|}
\hline \multirow[t]{3}{*}{ NPK (kg) } & \multicolumn{6}{|c|}{ Compost (t/ha) } \\
\hline & $\mathbf{0}$ & 1 & 2 & $\mathbf{0}$ & 1 & 2 \\
\hline & \multicolumn{3}{|c|}{ Panicle length } & \multicolumn{3}{|c|}{ Number of spikes } \\
\hline 0 & $31.89 \mathrm{e}$ & $28.96^{\mathrm{f}}$ & $33.97 \mathrm{~d}$ & $32.27^{f}$ & $51.79 \mathrm{~d}$ & $58.32^{c}$ \\
\hline 30 & $30.46^{\mathrm{e}}$ & $33.51^{\mathrm{d}}$ & $41.22^{\mathrm{b}}$ & $41.61^{e}$ & $57.38^{c}$ & $62.22^{\mathrm{ab}}$ \\
\hline 60 & $31.64^{\mathrm{e}}$ & $35.93^{c}$ & $44.20^{\mathrm{a}}$ & $56.38^{c}$ & $61.56^{b}$ & $64.51^{\mathrm{a}}$ \\
\hline LS & \multicolumn{3}{|c|}{$* *$} & \multicolumn{3}{|c|}{$* *$} \\
\hline $\mathrm{SE} \pm$ & \multicolumn{3}{|c|}{0.53} & \multicolumn{3}{|c|}{0.94} \\
\hline
\end{tabular}

LS = Level of significance, SE = Standard error, NS = Not significant, * \& ** = Significant @ 0.05 \& 0.01 probability level, Means followed by the same letter in a column are statistically same by DMRT. 
The significant $(\mathrm{P} \leq 0.05)$ difference observed in this experiment on number of spikes per panicle in which the rate of $60 \mathrm{~kg} \mathrm{NPK} /$ ha proved to be more better than the other treatment used revealed that, increase in number of spikes with increase in application of nitrogen fertilizer indicated the significance of inorganic fertilizer on number of spike in sorghum production. The present result support the report of [23], who reported a significant increase in number of spikes of sorghum following increase in NPK fertilizer. The application of $2 \mathrm{t} /$ ha poultry manure based compost gave significantly higher number of spikes. This proved the importance of compost application in sorghum production. This is in agreement with the report of [24] who reported a similar trend while study on compost. The significant difference observed with respect to spacing indicated that higher number of spikes were found with wider spacing. This revealed the effects of competition on yield characters of sorghum. The result of the interaction in which application of $60 \mathrm{~kg}$ $\mathrm{NPK} /$ ha with $2 \mathrm{t} /$ ha poultry manure based compost gave higher number of spikes, indicated the importance of combine application of organic and inorganic fertilizer in sorghum production. This is in line with the result of [15] who reported a significant increase in number of spikes of sorghum with combine application of organic and inorganic fertilizer.

\subsubsection{0-grain weight $(g)$}

The result of this experiment indicated that $60 \mathrm{~kg}$ NPK/ha produced higher 1000-grain weight. This revealed the importance of NPK fertilizer to cereal production. The result of this study support the result of [25], who reported a similar trend in legume-cereal intercrop. The significant difference observed with increase in poultry manure based compost revealed its significance in increasing yield of sorghum. This could be attributed to increase in organic carbon in the soil due to addition of compost. The result of this experiment is in conformity with the result of [26] who reported that grain weight was significantly affected by legume residue added to the soil and nitrogen fertilizer application during legume - cereal rotation. No significant difference was observed in terms of planting density. This is not in support of the report of [27] who reported that, wider spacing produced thicker stems of sorghum.

\subsubsection{Yield $(\mathrm{kg} / \mathrm{ha})$}

The significant $(\mathrm{P} \leq 0.05)$ difference observed in this study in which $60 \mathrm{~kg} \mathrm{NPK} / \mathrm{ha}$ yield higher than the other rates revealed that, the increase in yield with increase in nitrogen fertilizer application clearly indicates the importance of inorganic fertilizer in the performance of sorghum. This indicated the effect of nitrogen as a basic component of many physiological processes in plants. The present finding is in support of the report of [28] who reported that, nitrogen is a basic constituent of many compound of physiological importance to plant metabolism such as chlorophyll, nucleotide, alkaloids proteins, enzymes, hormones and vitamins. It was observed that, application of $2 \mathrm{t} /$ ha poultry manure based compost produced the highest yield of sorghum. This could be due to low carbon to nitrogen ratio of poultry manure and the effect of decomposition which lead to early release of plant nutrient in the soil. This is in line with the report of [13] who reported that composting organic matter will increase not only growth of crop, but also its nitrogen use efficiency. Higher grain yield were observed with wider spacing, this could be as a result of reduced competition for water and nutrients in the soil. This is in support of the report of [27], who reported that, wider spacing produced higher grain yield of sorghum.

The result of the interaction in which application of $60 \mathrm{~kg}$ NPK/ha with $2 \mathrm{t} /$ ha poultry manure based compost gave higher grain yield indicated the importance of combine application of organic and inorganic fertilizer in sorghum production. This is in line with the result of [15] who reported a significant increase in grain yield of sorghum with combine application of organic and inorganic fertilizer.

Table 8 Interaction of poultry manure based compost, NPK fertilizer and spacing on Panicle length

\begin{tabular}{cccccc}
\hline \multirow{2}{*}{$\begin{array}{c}\text { Compost } \\
\text { (t/ha) }\end{array}$} & \multicolumn{2}{c}{ Spacing (cm) } & \multicolumn{3}{c}{ NPK (kg) } \\
\cline { 2 - 6 } & $\mathbf{2 5 \times 7 5}$ & $\mathbf{3 0 \times 7 5}$ & $\mathbf{0}$ & $\mathbf{3 0}$ & $\mathbf{6 0}$ \\
\hline 0 & $30.27^{\mathrm{e}}$ & $30.43^{\mathrm{e}}$ & $1691.02^{\mathrm{d}}$ & $1902.32^{\mathrm{cd}}$ & $2621.45^{\mathrm{b}}$ \\
1 & $32.24^{\mathrm{d}}$ & $35.31^{\mathrm{c}}$ & $2071.33^{\mathrm{c}}$ & $2571.62^{\mathrm{b}}$ & $2792.78^{\mathrm{b}}$ \\
2 & $38.95^{\mathrm{b}}$ & $40.65^{\mathrm{a}}$ & $2570.34^{\mathrm{b}}$ & $3261.74^{\mathrm{a}}$ & $3462.89^{\mathrm{a}}$ \\
LS & & $*$ & & $*$ & \\
SE \pm & & 0.43 & & 93.91 &
\end{tabular}

LS = Level of significance, SE = Standard error, NS = Not significant, * \& ** = Significant @ 0.05 \& 0.01 probability level, Means followed by the same letter in a column are statistically same by DMRT. 


\section{Conclusion}

The application of NPK fertilizer had a significant effect on both growth and yield of sorghum. Similarly, the use of poultry manure based compost and its combination with NPK fertilizer can increase growth and yield of sorghum in the study area. The study also confirmed that, spacing of $30 \mathrm{~cm}$ x $75 \mathrm{~cm}$ gave higher yield of sorghum than $25 \mathrm{~cm} \times 75 \mathrm{~cm}$.

Based on the results obtained, the following recommendations were made:

- Application of $60 \mathrm{~kg}$ NPK/ha (20:10:10) to sorghum can be recommended for the study area.

- The use of poultry manure based compost and its combination with NPK fertilizer should be adopted by farmers for sorghum production in the study area.

- Since the combination of $60 \mathrm{~kg}$ NPK/ha and $2 \mathrm{t} / \mathrm{h}$ a poultry manure based compost was the highest level used producing the highest yield in the present study, further research should be conducted with higher levels to determine the right level that best suits the study area.

\section{Compliance with ethical standards}

\section{Acknowledgments}

All praises are due to Almighty God for His infinite mercy in sparing our lives and enabling us to reach the conclusion of this research work. We express our gratitude to all the staff of Department of Crop Production in particular, Faculty of Agriculture and the entire Abubakar Tafawa Balewa University in general. It is imperative to appreciate the support of tertiary education trust fund (TETFUND) of Nigeria for their support during the conduct of this research.

\section{Disclosure of conflict of interest}

The authors of this article declare that there is no conflict of interest.

\section{References}

[1] Bationo A and Mokwunye AU. (1991). Alleviating soil fertility constraints to increased production in West Africa. The experience in the Sahel. Fertilizer Research, 29, 95-115.

[2] Stoorvogel JJ and Smaling E. (2000). Assessment of soil nutrient depletion in sub-Saharan Africa, $1983-2000$. Main Report 28, DLO The Winang Staring Centre for Integrated Land, Soil and Water Research (SC-DLO), Wageningen, 1, 137.

[3] Brady NC and Weil R. (1999). The nature and properties of soil. 12 ${ }^{\text {th }}$ Edition. Mac. Pub. Com. New York, 625-640.

[4] Tenebe VA and Kamara HM. (2002). Effect of Striga hermonthica on the growth characteristics of sorghum intercropped with groundnut varieties. Journal of Agronomy and Crop Science, 188, 376-381.

[5] Akanbi WB, Adebayo TA, Togun AO, Adeyeye AS and Olaniran OA. (2007). The use of compost extracts as foliar spray nutrient source and botanical insecticide in Telfairia occidentalis. World Journal of Agricultural Sciences, 3(2), 145-154

[6] Akande MO, Oluwatoyinbo FI, Kayode CO, Olowokere FA. (2006). Response of maize (Zea mays) and okra (Abelmoschus esculentus) intercrop relayed with cowpea (Vigna unguiculata) to different levels of cow dung amended phosphate rock. World Journal of Agricultural Science, 2(1), 119-122.

[7] Mugwe J, Mugendi D, Kungu J and Muna MM. (2009). Maize yields response to application of organic and inorganic input under on-station and on-farm experiments in central Kenya. Experimental Agriculture, 45, 4759.

[8] Abedi T, Alemzadeh A and KazemeIni SA. (2010). Effect of organic and inorganic fertilizers on grain yield and protein banding pattern of wheat. Australian Journal of Crop Science, 4, 384-389.

[9] Kazemeini SA, Hamzehzarghani H, Edalat M. (2010). The impact of nitrogen and organic matter on winter canola seed yield and yield components. Australian Journal Crop Science, 4, 335- 342.

[10] Maharishnan KA, Sambasira S and Bhanu K. (2004). Effects of organic sources of plant nutrients in conjunction with chemical fertilizers on growth, yield and quality of rice. Research on Crops, 5, 159 -161. 
[11] Fagam AS, Buba UM, Yahaya IM and Olakanle FI. (2009). Effect of variety and nitrogen levels on growth, yield and yield components of maize (Zea mays l.) in Bauchi Nigeria. Proceedings of $23^{\text {rd }}$ annual national conference of farm management association of Nigeria, 14-17 th December 2009.

[12] Eghball B. (2002). Soil properties as influenced by phosphorus and nitrogen - based manure and compost applications. Agronomy Journal, 94, 128-135.

[13] Bationo A and Ntare BR. (2000). Rotation and nitrogen fertilizer effects on pearl millet, cowpea and groundnut yield and soil chemical properties in a sandy soil in the semi-arid tropics, West Africa. Journal of Agricultural Science, 134: 277-284.

[14] Ellis JR, Roder W and Masson SC. (1992). Grain sorghum - soybean rotation and fertilization influence on vesicular arbuscolar mycorrizal fungi. American Soil Science Society, 56, 789-794.

[15] Sanginga N, Okogun J, Vanlauwe B and Dashiel K. (2002). The contribution of nitrogen by promiscuous soybean to maize best cropping in the moist savannah of Nigeria. Plant and Soil, 241, 223-231.

[16] Bado BV, Bationo A and Cescas MP. (2006) Assessment of cowpea and groundnut contributions to soil fertility and succeeding sorghum yields in the Guinean savannah zone of Burkina Faso (West Africa). Biology and Fertility Soils, 43, 171-176.

[17] Staggenborg SA and Vanderlip RL. (1996). Sorghum grain yield reductions caused by duration and timing of freezing temperatures. Agronomy Journal, 88, 473-477.

[18] Akande MO, Adediran JA and Oluwatoyinbo FI. (2005). Effects of rock phosphate amended with poultry manure on soil available P and yield of maize and cowpea. African Journal of Biotechnology, 4, 444-448.

[19] Mohammad RH and Solaiman AH. (2012). Efficacy of organic and organic fertilizer on the growth of Brassica oleracea L. (Cabbage). International Journal of Agriculture and Crop Sciences, 4(3), 128-138

[20] Stoop WA and Staveren JPV. (1981). Effects of cowpea in cereal rotations on subsequent crop yields under semiarid conditions in Upper-Volta. In: Biological Nitrogen Fixation Technology for Tropical Agriculture. Graham PC and Harris SC. (Eds), Cali, Colombia: Centro International de Agricultura Tropical.

[21] Bado V, Sawodogo A, Thio B, Bationo A, Traore K and Cescas M. (2011). Nematode infestation and nitrogen effect of legumes on soil and crop yield in legumes - sorghum rotation. Agricultural Sciences, 2(2), 49-55

[22] Buerkert A, Bagayoko M, Aley S and Bationo A. (2001). Causes of legume rotation effect in increasing cereal yields across the Sudanian, sahelian and Guinian zone of West Africa. Plant Nutrition, Food Security and Sustainability of Agro-Ecosystem, 5, 972 - 978.

[23] Nottidge DO, Ojeniyi SO and Asawalam M. (2005). A comparative effect of plant residue and NPK fertilizer on nutrient status and yield of maize in a humid ultisol. Nigerian Journal of Soil Science, 15, 1-8.

[24] Carsky RJ, Singh L and Ndikawa R. (1994). Suppression of Striga hermonthica on sorghum using a cowpea intercrop. Experimental Agriculture, 30, 349-358.

[25] Musa EM, Elsheik EF, Mohammed IA and Babiker EE. (2011). Intercropping sorghum and cowpea: effect of bradyrhizobium inoculation and fertilization on mineral composition of cowpea seeds. International Journal of Agricultural Research and Review, 1(3), 138-146.

[26] Gary E, Varvel, N and Wilhelm W. (2003). Soybean nitrogen contribution to corn and sorghum in western cornbelt rotations. University of Nebraska, faculty of agronomy publication. $3^{\text {rd }}$ edition, 132-213.

[27] Madukwe DK, Christo IEC and Onuh MO. (2008). Effects of organic manure and cowpea (Vigna unguiculata (1.) Walp) varieties on the chemical properties of the soil and root nodulation. Science World Journal, 3 (1), 231 - 242

[28] Stewart BA, Musick JT and Dusek DA. (1993). Yield and water use efficiency of grain sorghum in a limited irrigation-dryland farming system. Agronomy Journal, 75, 629-634.

\section{How to cite this article}

Shuaibu YM, Fagam AS and Kawure S. (2018). Effects of poultry manure based compost and NPK fertilizer on the growth and yield of sorghum (Sorghum bicolor L. moench) in Bauchi state Nigeria. GSC Biological and Pharmaceutical Sciences, 2(2), 16-24. 